\title{
ANALISIS PELAKSANAAN AKUNTANSI SYARIAH UNTUK PEMBIAYAAN MURABAHAH SERTA KESESUAIANNYA TERHADAP PSAK NO. 102 PADA PT. BPRS SYARIKAT MADANI TANJUNGPINANG
}

\author{
Masyitah As Sahara \\ Sekolah Tinggi Ilmu Ekonomi (STIE) Pembangunan Tanjungpinang \\ masyitah@stie-pembangunan.ac.id \\ Yuni Rahmasari \\ Sekolah Tinggi Ilmu Ekonomi (STIE) Pembangunan Tanjungpinang \\ yunirahmasari06@gmail.com
}

\begin{abstract}
Abstrak: Penelitian ini bertujuan untuk menganalisis pelaksanaan akuntansi murabahah pada PT. BPRS Syarikat Madani Tanjungpinang dan kesesuaian pelaksanaan akuntansi murabahah yang diterapkan dengan PSAK No. 102 tentang akuntansi murabahah. Penelitian dilakukan di PT. BPRS Syarikat Madani Cabang Tanjungpinang dengan fokus penelitian pada pembiayaan murabahah dan pelaksanaan akuntansinya berdasarkan PSAK No. 102. Metode yang digunakan yaitu deskriptif kualitatif. Sedangkan metode pengumpulan data yaitu dokumentasi, wawancara, dan studi pustaka. Berdasarkan hasil penelitian yang dilakukan diketahui bahwa pelaksanaan akuntansi murabahah pada PT. BPRS Syarikat Madani Cabang Tanjungpinang belum sepenuhnya sesuai dengan prinsip akuntansi yang diterima umum yaitu, PSAK No. 102. Kesimpulan dari penelitian ini yaitu, adanya penerapan akad wakalah yang tidak sesuai dengan PSAK No. 102. Dalam hal pengakuan dan pengukuran yaitu saat penerapan diskon murabahah, implementasinya PT. BPRS Syarikat Madani Cabang Tanjungpinang tidak mengakui adanya diskon murabahah sehingga tidak melakukan pencatatan apapun atau tidak adanya perlakuan akuntansi terkait diskon murabahah. Serta dalam hal pengungkapan penyajian laporan keuangan syariah belum lengkap sesuai dengan standar penyajian laporan keuangan syariah.
\end{abstract}

Kata Kunci: murabahah, pelaksanaan akuntansi, PSAK No. 102.

Abstract: The purpose of this research were to analyze the implementation of murabahah accounting at PT. BPRS Syarikat Madani Tanjungpinang and the suitability of the implementation of murabahah accounting which is applied with PSAK No. 102 regarding murabahah accounting. The research was conducted at PT. BPRS Syarikat Madani Tanjungpinang Branch with a research focus on murabahah financing and the implementation of its accounting based on PSAK No. 102. The method used is descriptive qualitative. While the data collection methods are documentation, interviews, and literature review. Based on the results of research conducted, it is known that the implementation of murabahah accounting at PT. BPRS Syarikat Madani Tanjungpinang Branch is not fully in accordance with generally accepted accounting principles, namely, PSAK No. 102. The conclusion of this research is the implementation of the wakalah contract is not in accordance with PSAK No. 102. In terms of recognition and measurement, namely the implementation of the murabahah discount, the implementation of PT. BPRS Syarikat Madani, Tanjungpinang Branch does not recognize the murabahah discount, so it does not record anything or there is no accounting treatment related to the murabahah discount. As well as in terms of the disclosure of the presentation of Islamic financial statements is not complete in accordance with the standards of presentation of Islamic financial statements.

Keywords: Murabahah, accounting implementation, PSAK No. 102. 


\section{PENDAHULUAN}

Dunia perbankan tidak bisa dipisahkan dari dunia perekonomian. Dilihat dari segi bisnis, hampir segala aktivitas pendanaan menggunakan jasa perbankan sebagai lembaga keuangan yang mampu membantu berjalannya suatu bisnis. Sehingga seiring berjalannya waktu, perbankan menjadi kebutuhan hidup bagi masyarakat, melalui kegiatan pinjaman, perkreditan, pembiayaan serta berbagai jasa lain yang ditawarkan oleh perbankan. Dalam kegiatan tersebut lembaga perbankan akan berusaha untuk menawarkan produknya kepada nasabah, sementara nasabah dilain pihak akan berusaha menemukan produk yang dapat memenuhi kebutuhan serta keinginannya.

Berdasarkan pada jenis bank, bank dibedakan menjadi 2 yaitu, bank umum dan bank perkreditan rakyat. Serta berdasarkan penentuan harganya, bank dibagi menjadi 2 yaitu, bank konvensional dan bank syariah. Bank syariah ialah bank yang menjalankan kegiatan operasionalnya berdasarkan dengan syariah islam dengan sistem bagi hasil atau sistem bebas bunga. Ada beberapa jenis perbankan syariah yang ada, yaitu Bank Umum Syariah (BUS), Unit Usaha Syariah (UUS), dan Bank Pembiayaan Rakyat Syariah (BPRS). Bank Pembiayaan Rakyat Syariah atau biasa disingkat BPRS merupakan lembaga keuangan bank yang melayani masyarakat menengah, yang berfungsi sebagai pelaksana sebagian tugas bank umum. BPRS dalam menjalani kegiatan usahanya tidak memberikan jasa dalam lalu lintas pembayaran dengan mengacu pada prinsip syariah islam. Dalam kegiatan menyalurkan dana kepada nasabah atau yang biasa disebut dengan pembiayaan, ada beberapa akad yang digunakan oleh BPRS yaitu akad jual beli seperti murabahah, istishna, dan salam, dan akad bagi hasil seperti musyarakah dan mudharabah. Akad yang paling diminati atau yang paling banyak dilakukan oleh BPRS pada umumnya adalah murabahah.

Murabahah adalah suatu perjanjian jual beli suatu objek antara penjual dan pembeli. Dalam murabahah pada saat akad, barang yang diperjualbelikan harus ada, sementara pembayarannya bisa dilakukan dengan cicilan atau dengan tunai. Kedua belah pihak wajib menyepakati harga jual barang serta jangka waktu pembiayaannya. Pembiayaan murabahah yang diatur oleh Dewan Standar Akuntansi Keuangan Ikatan Akuntan Indonesia (DSAK IAI) yang menerbitkan Pernyataan Standar Akuntansi Keuangan (PSAK) Nomor 102 tentang Akuntansi Murabahah pada tanggal 27 Juni 2007. PSAK Nomor 102 mengatur mengenai hal pengakuan, pengukuran, penyajian, serta pengungkapan pada transaksi murabahah.

PT. BPRS Syarikat Madani Tanjungpinang merupakan salah satu bank yang menjalankan operasionalnya dengan prinsip syariah islam. PT. BPRS Syarikat Madani Cabang Tanjungpinang beralamat di KM. 8 Jalan D.I Panjaitan Km. 08, Komplek 
Ruko Cipta Madani No. 6, Tanjungpinang, Kepulauan Riau. Produk pembiayaan murabahah merupakan produk yang paling banyak diminati oleh nasabah PT. BPRS Syarikat Madani Cabang Tanjungpinang Seperti lembaga keuangan syariah yang lain, PT. BPRS Syarikat Madani Cabang Tanjungpinang wajib untuk menaati aturan tentang pelaksanan pembiayaan murabahah yang sudah diatur dalam PSAK Nomor 102 tentang akuntansi murabahah.

Namun dalam praktiknya, pihak PT. BPRS Syarikat Madani Cabang Tanjungpinang selaku penjual tidak menyediakan barang sebagai objek murabahah. Bank tidak bertindak sebagai penjual melainkan bertindak sebagai penyedia dana. Oleh sebab itu, bank tidak melakukan pembelian barang dari supplier, melainkan nasabah yang memesan sendiri barang kepada supplier. Dalam hal ini berbeda dengan konsep akuntansi murabahah yang diatur dalam PSAK Nomor 102 yang menyebutkan bahwa bank sebagai penjual dan nasabah sebagai pembeli. Sehingga menyebabkan ada beberapa akun yang tidak diakui apabila disesuaikan dengan PSAK Nomor 102. Selain itu, terdapat beberapa aspek yang belum sesuai dalam segi syarat dan rukunnya, saat dilakukannya akad, bank menambahkan akad wakalah yang dilakukan bersamaan dengan akad murabahah dalam pelaksanaannya. Hal tersebut kurang sesuai dengan ketentuan dalam PSAK Nomor 102. Selanjutnya dilihat dalam segi barang yang diperjualbelikan tidak jelas, disebabkan pihak nasabah sendiri yang melakukan pembelian barang. Sementara pihak bank hanya sebagai penyedia dana atau perantara pembiayaan saja. Dalam segi pembayaran, bank mengizinkan nasabah membayar uang muka kepada supplier dan barang dibeli atas nama nasabah.

Didasarkan pada permasalahan yang telah dijelaskan di atas, maka dari itu peneliti tertarik untuk melakukan penelitian pada objek dengan judul "Analisis Pelaksanaan Akuntansi Syariah Untuk Pembiayaan Murabahah Serta Kesesuaiannya Terhadap PSAK Nomor 102 Pada PT. BPRS Syarikat Madani Tanjungpinang”. TINJAUAN PUSTAKA

\subsection{Pembiayaan}

Menurut Asiyah (2015) berpendapat bahwa pembiayaan atau financing merupakan pemberian dana yang ditujukan dari satu pihak kepada pihak yang lain guna mendukung investasi yang sudah terencana, baik yang dijalankan secara pribadi ataupun berlembaga.

Pembiayaan merupakan penyaluran uang atau tagihan yang disetarakan dengan antara lain:

- Pembiayaan musyarakah dan mudharabah atas transaksi bagi hasil.

- Pembiayaan Ijarah muntahiya bittamlik atas transaksi sewa beli dan pembiayaan ijarah atas transaksi sewa menyewa.

- Pembiayaan murabahah, salam, dan istishna atas transaksi jual beli. 
- Pembiayaan qardh atas transaksi pinjam meminjam.

\subsection{Murabahah}

Menurut Hakim (2012) kata murabahah bermula dari bahasa Arab yaitu ribh yang berarti keuntungan. Sementara dalam istilah, murabahah adalah perjanjian jual beli suatu barang tertentu, yang di mana si penjual harus memberitahu harga jual yang terdiri atas harga perolehan barang ditambah persentase keuntungan tertentu atas suatu barang, dan pembeli harus menyetujui harga jual tersebut.

Menurut Nurhayati \& Wasilah

(2015) ada beberapa jenis-jenis

murabahah yang diterapak oleh bank

syariah, antara lain:

\subsubsection{Murabahah berdasarkan pesanan}

Murabahah dalam pesanan, biasanya bersifat mengikat ataupun tidak mengikat nasabah dalam pembelian barang pesanannya. Dalam jenis ini, selaku penjual pihak bank melakukan pemesanan barang kepada supplier setelah mendapat pesanan dari nasabah selaku pembeli.

\subsubsection{Murabahah tanpa pesanan}

Kepemilikan suatu barang/benda oleh bank biasanya disebut dengan murabahah tanpa pesanan. Dalam murabahah tanpa pesanan, biasanya bersifat tidak mengikat. Murabahah tanpa pesanan berarti ada yang memesan atau tidak ada yang membeli, bank akan tetap menyediakan barang jualannya.

\subsection{PSAK Nomor 102 tentang Akuntansi} Murabahah

Dewan Standar Akuntansi Keuangan Ikatan Akuntan Indonesia (DSAK IAI) menerbitkan Pernyataan Standar Akuntansi Keuangan (PSAK) Nomor 102 tentang akuntansi murabahah pada tanggal 27 Juni 2007.

PSAK Nomor 102 tentang Akuntansi Murabahah mengatur tentang aspek pengakuan, pengukuran, penyajian, serta pengungkapan atas transaksi pembiayaan murabahah. Dalam ruang lingkup pernyataan ini dilaksanakan bagi koperasi syariah dan lembaga keuangan syariah yang menjalankan transaksi atas pembiayaan murabahah sebagai penjual ataupun sebagai pembeli serta pihakpihak yang menjalankan transaksi pembiayan murabahah. Dalam PSAK Nomor 102 tidak meliputi peraturan pada pelaksanaan akuntansi terhadap obligasi syariah serta sukuk yang melakukan akad murabahah (Asiyah, 2015).

Selanjutnya Dewan Standar Akuntansi Syariah dan Ikatan Akuntan Indonesia (2017) menyatakan bahwa pengakuan dan pengukuran akuntansi murabahah dalam PSAK Nomor 102 yang terkandung dalam paragraf 18 sampai dengan paragraf 30 , menyangkut hal:

1. Pada saat perolehan, aset murabahah diakui sebagai persediaan sebesar biaya perolehan. 
2. Pengukuran aset murabahah setelah perolehan yaitu sebagai berikut:

a. Apabila murabahah pesanan mengikat:

(i) Dinilai sebesar biaya perolehan;

(ii) Jika terjadi penurunan nilai aset karena rusak, usang, atau kondisi lain yang sebelum diserahkan ke nasabah, penurunan nilai tersebut diakui sebagai beban dan akan mengurangi nilai aset.

b. Apabila murabahah tanpa pesanan atau murabahah pesanan tidak mengikat:

(i) Dinilai berdasarkan biaya perolehan atau nilai bersih yang dapat direalisasi, mana yang lebih rendah;

(ii) Apabila nilai neto yang dapat direalisasi lebih rendah dari biaya perolehan, maka selisihnya diakui sebagai kerugian.

3. Diskon pembelian aset murabahah diakui:

a. Apabila terjadi sebelum akad murabahah maka sebagai pengurangan biaya perolehan aset murabahah;

b. Apabila terjadi setelah akad murabahah dan sesuai akad yang disepakati maka bagian yang menjadi hak nasabah;

c. Apabila terjadi setelah akad murabahah dan sesuai akad yang menjadi bagian hak lembaga keuangan syariah diakui sebagai tambahan margin murabahah;

d. Apabila terjadi setelah akad murabahah dan tidak diperjanjikan dalam akad diakui sebagai pendapatan operasional lain.

4. Pengakuan piutang. Pada saat akad murabahah, piutang murabahah diakui sebesar biaya perolehan aset murabahah ditambah keuntungan yang disepakati. Pada akhir periode laporan keuangan, piutang murabahah dinilai sebesar nilai bersih yang dapat direalisasi, yaitu saldo piutang dikurangi penyisihan kerugian piutang.

5. Pengakuan keuntungan

Keuntungan murabahah diakui:

a. Pada saat akad murabahah dilakukan secara tunai atau secara tangguh sepanjang masa angsuran murabahah tidak melebihi satu periode laporan keuangan; atau

b. Selama periode akad secara proporsional, jika akad melampaui satu periode keuangan.

6. Potongan pelunasan piutang murabahah yang diberikan kepada pembeli yang melunasi secara tepat waktu atau lebih cepat dari waktu yang disepakati diakui sebagai pengurang keuntungan murabahah.

7. Potongan angsuran murabahah diakui:

a. Apabila disebabkan oleh pembeli yang membayar secara tepat waktu 
diakui sebagai pengurang keuntungan murabahah;

b. Apabila disebabkan oleh penurunan kemampuan pembayaran pembeli diakui sebagai beban.

8. Pengakuan denda. Denda dikenakan kepada pembeli yang lalai dalam melakukan kewajibannya sesuai dengan akad, denda yang diterima diakui sebagai dana kebajikan.

9. Pengakuan dan pengukuran uang muka:

a. Uang muka diakui sebagai uang muka pembelian sebesar jumlah yang diterima;

b. Jika barang jadi dibeli oleh pembeli, maka uang muka diakui sebagai pembayaran piutang bagian dari pokok;

c. Apabila barang batal dibeli oleh pembeli, maka uang muka dikembalikan kepada pembeli setelah di perhitungkan dengan biaya yang telah dikeluarkan.

PSAK Nomor 102 yang menyatakan tentang penyajian akuntansi murabahah terkandung dalam paragraf 37 sampai dengan paragraf 39, ialah sebagai berikut:

1. Piutang murabahah disajikan sejumlah nilai neto yang dapat direalisasikan, yaitu saldo piutang murabahah dikurangi penyisihan kerugian piutang.

2. Margin murabahah tangguhan disajikan sebagai pengurang (contra account) piutang murabahah.
3. Beban murabahah tangguhan disajikan sebagai pengurang (contra account) utang murabahah.

Selanjutnya, PSAK Nomor 102 yang menyatakan tentang pengungkapan akuntansi murabahah terkandung dalam paragraf 40 dan paragraf 41, ialah sebagai berikut:

1. Penjual mengungkapkan hal yang berkaitan dengan transaksi murabahah, namun tidak terbatas pada:

a. Harga perolehan aset murabahah

b. Janji pemesanan dalam murabahah berdasarkan pesanan sebagai kewajiban atau bukan, dan pengungkapan yang diperlakukan sesuai PSAK Nomor 101: Penyajian Laporan Keuangan Syariah.

2. Pembeli mengungkapkan hal yang berkaitan dengan transaksi murabahah, namun tidak terbatas pada:

a. Nilai tunai aset yang diperoleh dari transaksi murabahah

b. Jangka waktu murabahah tangguh.

\section{METODE PENELITIAN}

\subsection{Jenis Penelitian}

Dalam penelitian ini, jenis penelitian yang digunakan adalah deskriptif kualitatif. Menurut Sugiyono (2017) berpendapat bahwa penelitian deskriptif merupakan penelitian yang dilakukan agar dapat memberikan gambaran lebih detail tentang suatu fenomena atau gejala yang sedang diteliti. 


\subsection{Jenis Data}

Dalam penelitian ini, jenis data yang digunakan yaitu data primer dan sekunder. Menurut Indriantoro dan Supomo (2018) menyatakan bahwa data primer ialah sumber data penelitian dari sumber aslinya atau tidak melalui media perantara yang didapat secara langsung. Sedangkan data sekunder menurut Sujarweni (2015) merupakan data yang diperoleh dari catatan, dan buku berupa laporan keuangan publikasi bank, buku-buku sebagai teori, artikel, dan lain-lain.

\subsection{Teknik Pengumpulan Data}

Teknik pengumpulan data adalah cara yang paling pertama untuk melakukan penelitian, karena mendapatkan data adalah tujuan utama dari penelitian. Teknik pengumpulan data berguna untuk memperoleh data yang akurat tentang objek penelitian. Teknik pengumpulan data yang dilakukan oleh peneliti dalam penelitian ini yaitu, dokumentasi, wawancara, dan studi pustaka.

\subsection{Teknik Pengolahan Data}

Menurut Arikunto (2014) mengolah data dan menganalisis data adalah aktivitas mengubah data mentah menjadi data yang lebih bermakna yang mengarah pada kesimpulan.

Jenis penelitian deskriptif kualitatif ini menggunakan teknik pengolahan data yang didapat dari klarifikasi data-data. Adapun langkah-langkah yang dilakukan oleh peneliti dalam melakukan teknik pengolahan data yaitu data collection, data reduction, data display, dan Conclusion Drawing/Verification.

\subsection{Teknik Analisis Data}

Menurut Sugiyono (2017) analisis data yaitu proses mencari dan menyusun secara sistematis data yang diperoleh dari hasil wawancara dan dokumentasi dengan mengorganisasikan data atau mengelompokkan data sesuai dengan kategori, mengerjakan sintesa, menyusun ke dalam pola, memilah dan memilih data yang lebih penting yang akan dipelajari, serta membuat kesimpulan sehingga lebih mudah dalam memahami untuk diri sendiri dan juga orang lain. Teknik analisis data yang dilakukan dalam penelitain ini, yaitu:

- Meninjau objek penelitian

- Mengumpulkan data dan informasi mengenai pembiayaan murabahah.

- Mengkaji data dan informasi tentang pembiayaan murabahah.

- Melakukan pengolahan dan menganalisis data dengan cara membandingkan antara pengaplikasian pembiayaan murabahah yang terjadi di bank dengan kesesuaian PSAK 102.

- Melakukan evaluasi terhadap pencatatan pembiayaan murabahah. 
- Menarik kesimpulan atas hasil penelitian serta memberikan saransaran.

\section{HASIL DAN PEMBAHASAN}

Berikut contoh transaksi pembiayaan murabahah pada pembelian kendaraan berupa 1 unit mobil: Bapak Yusuf Santoso merupakan nasabah BPRS Syarikat Madani Cabang Tanjungpinang, dia akan mengajukan permohonan pembiayaan murabahah berupa 1 unit kendaraan mobil. Dana yang dibutuhkan olehnya sebesar Rp 80.000.000,-. Lalu bank menyetujui untuk memberikan pembiayaan sejumlah $\mathrm{Rp}$ 72.000.000,-, sedangkan Rp 8.000.000,merupakan uang muka. Dengan diketahui margin murabahah sebesar $12 \%$ dari harga pokok. Jangka waktu angsuran ditetapkan selama 2 tahun atau 24 bulan. Maka total pembiayaan murabahah yang harus dibayar oleh nasabah adalah Rp 72.000.000 + Rp $8.640 .000=\operatorname{Rp} 80.640 .000$, dengan angsuran per bulan sebesar Rp 3.360.000,-

\subsection{Analisis Kesesuaian Pengakuan dan}

Pengukuran Akuntansi Pembiayaan Murabahah di PT. BPRS Syarikat Madani Cabang Tanjungpinang

\subsubsection{Pengakuan Aset Murabahah (Paragraf 18)}

Pada praktiknya, akad yang dilakukan berupa akad murabahah bil wakalah sehingga pembelian aset diwakilkan kepada nasabah yang akan melakukan pembiayaan. PT. BPRS Syarikat Madani Cabang Tanjungpinang tidak menyediakan aset murabahah tanpa adaya pesanan terlebih dahulu dari nasabah.

Dalam hal ini membuat bank berperan sebagai lembaga pembiayaan sehingga tidak memiliki risiko kepemilikan persediaan aset. Namun bank tetap melakukan pencatatan terkait pengakuan persediaanmurabahah dalam kebijakan akuntansinya.

Persediaan Rp 72.000.000

Kas Rp 72.000.000

Maka pencatatan yang dilakukan oleh PT. BPRS Syarikat Madani Cabang Tanjungpinang telah sesuai dengan PSAK Nomor 102 pargaraf 18

\subsubsection{Diskon Murabahah (Paragraf 20)}

PT. BPRS Syarikat Madani Cabang Tanjungpinang tidak mengakui adanya diskon murabahah sehingga bank tidak melakukan pencatatan untuk diskon murabahah, maka pencatatan yang dilakukan oleh PT. BPRS Syarikat Madani Cabang Tanjungpinang tidak sesuai dengan PSAK Nomor 102 pargaraf 20.

\subsubsection{Piutang Murabahah (Paragraf 22)}


Piutang murabahah yang diberikan oleh PT. BPRS Syarikat Madani Cabang Tanjungpinang diakui sebesar biaya perolehan aset murabahah tersebut dan ditambah dengan margin keuntungan yang disepakati antara pihak nasabah dan pihak bank.

Pencatatan jurnal yang dilakukan oleh bank saat akad murabahah disepakati, yaitu:

Piutang Murabahah $\quad \mathrm{Rp} 80.640 .000$

Persediaan Rp 72.000 .000

Margin $\quad$ Rp 8.640.000

Dalam pengakuan dan pengukuran atas pencatatan piutang murabahah sebesar biaya perolehan aset murabahah dan ditambah margin keuntungan yang disepakati, maka pencatatan yang dilakukan oleh PT. BPRS Syarikat Madani Cabang Tanjungpinang telah sesuai dengan PSAK Nomor 102 paragraf 22.

\subsubsection{Keuntungan Murabahah (Paragraf} 23b)

Nilai margin keuntungan ditentukan oleh kebijakan bank dengan dilihat dari seberapa besar nilai objek murabahah dari supplier. Pihak bank menerima margin keuntungan tersebut pada saat nasabah melakukan pembayaran angsuran setiap bulannya sebelum tanggal jatuh tempo yang telah ditetapkan oleh pihak bank.
Jurnal pada saat penerimaan angsuran yang dilakukan oleh PT. BPRS Syarikat Madani Cabang Tanjungpinang, yaitu:

Kas

$$
\text { Rp 3.360.000 }
$$

Piutang Murabahah

Rp 3.360.000

Margin

Rp 360.000

Pendapatan Margin

Rp 360.000

Dalam pengakuan atas keuntungan murabahah diakui secara proporsional dengan besaran kas yang berhasil ditagih dari piutang murabahah. Maka pencatatan yang dilakukan oleh PT. BPRS Syarikat Madani Cabang Tanjungpinang telah sesuai dengan PSAK Nomor 102 paragraf 23b.

\subsubsection{Potongan Pelunasan Piutang Murabahah (Paragraf 26)}

PT. BPRS Syarikat Madani Cabang Tanjungpinang memberikan hak untuk nasabah dalam memberi potongan pada margin murabahah ataupun margin murabahah tidak dibayar oleh nasabah karena potongan tersebut merupakan pembayaran pelunasan dini. Pada saat potongan pelunasan dini maka pencatatan jurnal oleh bank, yaitu:

Pendapatan margin Rp 8.640.000

Piutang Murabahah Rp 8.640.000 
PT. BPRS Syarikat Madani Cabang Tanjungpinang mengakui adanya potongan pelunasan dini bagi nasabah yang melunasi Kas Rp 15.000 kewajibannya secara tepat waktu atau lebih cepat dari waktu yang disepakati. Maka pencatatan yang dilakukan oleh BPRS Syarikat Madani Cabang Tanjungpinang telah sesuai dengan PSAK Nomor 102 paragraf 26.

\subsubsection{Denda (Paragraf 29)}

Denda dikenakan apabila nasabah lalai dalam melakukan kewajibannya sesuai dengan akad, serta denda yang diterima diakui sebagai bagian dari dana kebajikan. Contoh: Nasabah atas nama Yusuf Santoso memiliki angsuran mobil dengan menggunakan akad murabahah setiap bulannya sejumlah Rp 3.360.000,- yang terdiri dari $\mathrm{Rp}$ 3.000.000,- merupakan pokok pembiayaan dan $\mathrm{Rp}$ 360.000,merupakan margin. Denda ditetapkan 0,5\% dari harga pokok yang belum dibayar. Maka perhitungan dendanya adalah sebagai berikut: $\operatorname{Rp} 3.000 .000$ x 0,5\% = Rp 15.000, Jadi, denda yang dikenakan kepada Yusuf Santoso karena mengalami keterlambatan pembayaran setelah tanggal jatuh tempo sebesar Rp 15.000,-.

Pencatatan akuntansi yang dilakukan oleh PT. BPRS Syarikat Madani Cabang Tanjungpinang terhadap denda murabahah adalah:

PT. BPRS Syarikat Madani Cabang Tanjungpinang mengakui denda sebagai dana kebajikan. Maka pencatatan yang dilakukan oleh BPRS Syarikat Madani Cabang Tanjungpinang telah sesuai dengan PSAK Nomor 102 paragraf 29.

\subsubsection{Uang Muka (Paragraf 30)}

PT. BPRS Syarikat Madani Cabang Tanjungpinang mengakui uang muka murabahah sebagai bagian dari pembayaran piutang murabahah. Berdasarkan pembiayaan pada contoh di atas dapat diketahui bahwa uang muka yang disepakati adalah sebesar 10\% dari harga dasar kendaraan mobil sebesar $\mathrm{Rp}$ 80.000.000,- dan uang muka sejumlah Rp 8.000.000,-. Pembayaran uang muka oleh nasabah langsung diserahkan kepada supplier, maka bank tidak menerimanya. Sehingga bank tidak melakukan pencatatan terkait uang muka murabahah. Maka pencatatan yang dilakukan oleh BPRS Syarikat Madani Cabang Tanjungpinang telah sesuai dengan PSAK Nomor 102 paragraf 30 .

\subsection{Analisis Kesesuaian Penyajian} Akuntansi Pembiayaan Murabahah di 
PT. BPRS Syarikat Madani Cabang Tanjungpinang

\subsubsection{Piutang Murabahah (Paragraf 37)}

Dalam neraca piutang disajikan dalam jumlah bruto piutang karena piutang yang tidak dapat direalisasikan hanya berdasarkan pada taksiran. Penyajian piutang murabahah ada di bawah kas dan bank, karena piutang murabahah adalah bagian dari aktiva lancar. Maka penyajian yang dilakukan oleh PT. BPRS Syarikat Madani Cabang Tanjungpinang telah sesuai dengan PSAK Nomor 102 paragraf 37.

\subsubsection{Margin Murabahah Tangguhan (Paragraf 38)}

Margin murabahah tangguhan disajikan di laporan neraca sebagai pengurang piutang murabahah. Pada PT. BPRS Syarikat Madani Tanjungpinang, pihak bank menyajikan margin murabahah tangguhan dalam laporan neraca bank dan tidak dalam laporan publikasi bank, hanya untuk laporan internal bank saja. Maka penyajian yang dilakukan oleh PT. BPRS Syarikat Madani Cabang Tanjungpinang telah sesuai dengan PSAK Nomor 102 paragraf 38 .

\subsubsection{Beban Murabahah Tangguhan (Paragraf 39)}

Beban murabahah tangguhan diamortisasi secara proporsional sesuai dengan porsi pelunasan utang murabahah. Penyajian atas beban murabahah tangguhan disajikan sebagai pengurang utang murabahah. Maka penyajian yang dilakukan oleh PT. BPRS Syarikat Madani Cabang Tanjungpinang telah sesuai dengan PSAK Nomor 102 paragraf 39.

\subsection{Analisis Kesesuaian Pengungkapan} Akuntansi Pembiayaan Murabahah di PT. BPRS Syarikat Madani Cabang Tanjungpinang

PT. BPRS Syarikat Madani Cabang Tanjungpinang mengungkapkan hal yang berkaitan dengan proses pengajuan pembiayaan murabahah, yaitu seperti: nilai perolehan aset, margin murabahah, piutang murabahah, biaya administrasi, dan sebagainya. Pengungkapan yang dibutuhkan terkait penyajian laporan keuangan syariah harus disesuaikan dengan PSAK Nomor 101.

Pengungkapan atas penyajian laporan keuangan syariah di PT. BPRS Syarikat Madani Cabang Tanjungpinang masih belum lengkap sesuai dengan PSAK Nomor 101. Maka dalam hal pengungkapan akuntansi murabahah di PT. BPRS Syarikat Madani Cabang Tanjungpinang tidak sesuai dengan PSAK Nomor 102 paragraf 40.

\section{PENUTUP}

\section{Simpulan}


Berdasarkan hasil penelitian dan pembahasan yang telah dilakukan pada PT. BPRS Syarikat Madani Cabang Tanjungpinang terhadap pembiayaan murabahah dan pelaksanan akuntansinya berdasarkan pada PSAK Nomor 102 tentang akuntansi murabahah, sehingga dapat ditarik kesimpulan berikut ini:

1. Pelaksanaan akuntansi murabahah pada PT. BPRS Syarikat Madani Cabang Tanjungpinang belum sepenuhnya sesuai dengan PSAK No. 102 tentang akuntansi murabahah. Perlakuan akuntansi murabahah yang meliputi pengakuan, pengukuran, penyajian, dan pengungkapan atas transaksi murabahah. Dalam hal penyajian akuntansi murabahah telah sesuai dengan PSAK Nomor 102.

2. PT. BPRS Syarikat Madani Cabang Tanjungpinang tidak berperan sebagai penjual, melainkan sebagai pihak yang menyediakan dana yang menggabungkan dua akad sekaligus, yaitu akad murabahah dan akad wakalah. PT. BPRS Syarikat Madani Cabang Tanjungpinang tetap melakukan pencatatan terhadap pengakuan persediaan murabahah dalam pencatatan akuntansinya, walaupun bank berperan sebagai lembaga pemberi pinjaman.

3. Perlakuan akuntansi murabahah yang tidak sesuai dengan PSAK Nomor 102 mengenai pengakuan dan pengukuran yaitu diskon murabahah.
4. Perlakuan akuntansi murabahah dalam hal pengungkapan tidak sesuai dengan PSAK Nomor 102. Pengungkapan dalam penyajian laporan keuangan syariah yang diperlukan harus sesuai dengan berdasarkan atas PSAK Nomor 101 tentang Penyajian Laporan Keuangan Syariah.

\section{Saran}

Berdasarkan atas kesimpulan yang telah dikemukakan diatas oleh penulis, maka saran yang dapat penulis berikan kepada PT. BPRS Syarikat Madani Cabang Tanjungpinang mengenai pembiayaan murabahah dan perlakuan akuntansinya, yaitu:

1. PT. BPRS Syarikat Madani Tanjungpinang lebih baik memisahkan antara dua akad yang digabungkan yaitu akad murabahah dan wakalah yang sudah diterapkan sebelumnya supaya fungsi bank dalam hal pembiayaan murabahah ini dilakukan sesuai dengan aturannya yaitu, bank sebagai penjual bukan hanya sebagai penyedia pinjaman saja.

2. Perlu dilakukan pengakuan dan pencatatan atas perlakuan akuntansi apabila menerima diskon murabahah sesuai dengan PSAK Nomor 102 yang merupakan standar akuntansi yang berlaku umum untuk menjaga rasa kepercayaan dan keterbukaan kepada nasabah.

3. Diharapkan PT. BPRS Syarikat Madani Cabang Tanjungpinang menyajikan laporan keuangan yang lengkap sesuai 
dengan PSAK Nomor 101. Dimana

laporan keuangan yang lengkap dapat

mencerminkan kewajaran dalam penilaian

seluruh kegiatan yang terjadi di bank syariah.

4. Menyadari akan kurangnya dokumen dan bukti pendukung pada penelitian ini, maka untuk penelitian selanjutnya dengan tema yang sama peneliti menyarankan agar dapat lebih melengkapi dokumen dari bank sebagai lampiran resmi tentang pembiayaan murabahah yang diterapkan oleh bank syariah.
DAFTAR PUSTAKA

Arikunto, S. (2014). Prosedur Penelitian Suatu Pendekatan Praktik. Jakarta: Rineka Cipta.

Asiyah, B. N. (2015). Manajemen Pembiayaan Bank Syariah. Yogyakarta: Kalimeda.

Dewan Standar Akuntansi Syariah, \& Ikatan Akuntan Indonesia. (2017). Standar Akuntansi Keuangan Syariah. (Ikatan Akuntan Indonesia,Ed.).

Hakim, L. (2012). Prinsip-Prinsip Ekonomi Islam. Yogyakarta: Erlangga.

Indriantoro, N., \& Supomo, B. (2018). Metodologi Penelitian Bisnis. Yogyakarta: ANDI.

Nurhayati, S., \& Wasilah. (2015). Akuntansi Syariah di Indonesia Edisi 4. Jakarta: Salemba Empat.

Sugiyono. (2017). Metode Penelitian Kuantitatif, Kualitatif, dan R\&D. Bandung: Alfabeta.

Sujarweni, V. R. (2015). Metodologi Penelitian Bisnis \& Ekonomi. Yogyakarta: Pustaka Baru Press. 